\title{
PENINGKATAN SISTEM IMUN OLEH KOMBINASI EKSTRAK ETANOL DAUN AWAR - AWAR (Ficus septica burm. F) DAN EKSTRAK ETANOL DAUN KELOR (Moringa oleifera) SEBAGAI KO- KEMOTERAPI KANKER PADA TIKUS PUTIH BETINA GALUR SPRAGUE DAWLEY YANG DIINDUKSI DOKSORUBISIN
}

\author{
EFFECT OF COMBINATION IMMUNE SYSTEM ENHANCEMENT \\ AWAR-AWAR (Ficus septica burm. F) LEAF ETHANOL EXTRACT AND \\ MORINGA (Moringa oleifera) LEAF ETHANOL EXTRACT AS CO- \\ CHEMOTHERAPY CANCER IN RATS FEMALE SPRAGUE DAWLEY \\ STRAIN INDUCED BY DOXORUBICIN
}

\author{
Dewi Indah Sari, Annisa Hardikasari Yazin, Rizka Angerti Anovia, Ulfa Ismayani, \\ Endang Darmawan \\ Fakultas Farmasi Universitas Ahmad Dahlan \\ Jln. Prof. Dr. Soepomo, Janturan, Yogyakarta, Telp. (0274) 379418 \\ Email: rizkachan95@yahoo.com
}

Submitted : 05-06-2015 Reviewed : 15-06-2015

Accepted: 23-11-2015

\begin{abstract}
ABSTRAK
Penggunaan obat doksorubisin untuk terapi kanker menyebabkan sistem imun tubuh menurun. Daun awar-awar dan daun kelor merupakan tanaman herbal yang memiliki manfaat sebagai agen imunostimulan atau meningkatkan sistem kekebalan tubuh. Adapun tujuan penelitian ini untuk mengetahui efek kombinasi ekstrak etanol daun awar-awar dan ekstrak etanol daun kelor sebagai kokemoterapi kanker pada tikus putih betina galur Sprague Dawley yang terinduksi doksorubisin. Delapan belas ekor tikus Sprague Dawley dibagi menjadi 6 kelompok perlakuan, yaitu kelompok normal diberi $\mathrm{NaCl} 0,9 \% 10 \mathrm{ml} / \mathrm{kgBB}$, kelompok kontrol positif diberi doksorubisin dosis 4,67 $\mathrm{mg} / \mathrm{kgBB}$, kelompok perlakuan dosis tunggal yang masing-masing diberi ekstrak etanol daun awarawar dosis $750 \mathrm{mg} / \mathrm{kgBB}$ dan ekstrak etanol daun kelor $500 \mathrm{mg} / \mathrm{kgBB}$, kelompok perlakuan yang masing- masing diberi kombinasi ekstrak etanol daun awar-awar dan daun kelor dengan dosis 1,25 $\mathrm{g} / \mathrm{kgBB}$ dan dosis $1,75 \mathrm{~g} / \mathrm{kgBB}$. Perlakuan dilakukan selama 7 hari berturut turut. Pada hari ke-1 dan ke-4 masing masing kelompok perlakuan kecuali kelompok normal diinduksi doksorubisin 4,67 $\mathrm{mg} / \mathrm{kgBB}$ secara intramuskuler. Pengambilan darah untuk pemeriksaan limfosit CD3+ dan limfosit CD8+ dilakukan pada hari ke-0 dan ke-7. Hasil penelitian menunjukkan bahwa kombinasi ekstrak etanol daun awar-awar dan daun kelor dosis $1,25 \mathrm{~g} / \mathrm{kgBB}$ dan dosis $1,75 \mathrm{~g} / \mathrm{kgBB}$ dapat meningkatkan sistem imun relatif kecil yang secara statistik tidak berbeda signifikan $(p>0,05)$. Namun pemberian dosis tunggal ekstrak etanol daun kelor dosis $500 \mathrm{mg} / \mathrm{kgBB}$ memiliki aktivitas sebagai imunostimulator terhadap $\mathrm{CD}^{+}$dan $\mathrm{CD}^{+}$yang lebih efektif jika dibandingkan dengan pemberian dosis tunggal ekstrak etanol daun awar-awar dosis $750 \mathrm{mg} / \mathrm{kgBB}$.
\end{abstract}

Kata Kunci : doksorubisin, daun awar-awar, daun kelor, limfosit CD3+ dan limfosit CD8+ limfosit.

\section{ABSTRACT}

Use of the drug doxorubicin for cancer therapy causes decreasing of immune system reported. Leaves of Ficus septica Burm. F and leaves of Moringa oleifera as immunostimulatory agents. The 
purpose of this study, among others, determine the combined effects of ethanol extract of Ficus septica Burm. F leaves and ethanol extract of Moringa oleifera leaves as co-chemotherapy for in female rats Sprague Dawley strain induced doxorubicin. Eighteen Sprague Dawley rats were divided into six treatment groups, normal group was given $0.9 \% \mathrm{NaCl} 10 \mathrm{ml} / \mathrm{kgBB}$, positive control group were given by doxorubicin with dose of $4.67 \mathrm{mg} / \mathrm{kgBB}$, single-dose treatment group were each given ethanol extract of Ficus septica Burm F leaves dose of $750 \mathrm{mg} / \mathrm{kgBB}$ and ethanol extract of Moringa oleifera leaves $500 \mathrm{mg} / \mathrm{kgBB}$, treatment groups were given by combination of ethanol extract Ficus septica Burm. F leaves and Moringa oleifera leaves with a dose of $1.25 \mathrm{~g} / \mathrm{kgBB}$ and a dose of 1,75 $\mathrm{g} / \mathrm{kgBB}$. treatment carried out for 7 days. On days 1 and 4 of each treatment groups except the normal group induced by doxorubicin $4.67 \mathrm{mg} / \mathrm{kgBB}$ intramuscularly. Blood sampling performed on day 0 and 7 th for lymphocytes CD3+ and lymphocytes CD8+ test. The results showed that the combination of ethanol extract Ficus septica burm. F leaves and Moringa oleifera leaves dose of 1.25 $\mathrm{g} / \mathrm{kgBB}$ and the dose of $1.75 \mathrm{~g} / \mathrm{kgBB}$ can enhanched immune system relative small which was not statistically significantly different ( $\mathrm{p}>0.05$ ). However, a single dose of ethanol extract Moringa oleifera leaves dose of $500 \mathrm{mg} / \mathrm{kg}$ have immunostimulatory activity as lymphocytes CD3+ and lymphocytes CD8+ were more effective than a single dose of ethanol extract of Ficus septica Burm. F leaves dose of $750 \mathrm{mg} / \mathrm{kgBB}$.

Keywords: doxorubicin, Ficus septica Burm. F leaves, Moringa oleifera leaves, lymphocytes CD3+ and lymphocytes CD8+.

\section{PENDAHULUAN}

Kanker merupakan penyebab utama kematian di dunia. Sekitar 13\% dari semua kematian akibat kanker terjadi pada tahun 2008, dan lebih dari 70\% dari semua kematian akibat kanker terjadi di negaranegara berkembang (WHO, 2011).

Penyakit ini terkait dengan pertumbuhan yang cepat dari sel-sel abnormal tidak terkendali di dalam tubuh serta memiliki kapasitas untuk menyerang jaringan sekitarnya menyebar ke organ lain, dikenal sebagai metastatis (Hanahan dan Weinberg, 2000).

Doksorubisin adalah salah satu obat yang sering digunakan untuk kemoterapi kanker (Tan et al., 2009). Namun, penggunaan doksorubisin memiliki beberapa efek samping. Salah satu efek samping adalah penurunan jumlah limfosit serta rasio CD4+/CD8+. Penggunaan doksorubisin dapat menyebabkan kardiotoksisitas dan sistem kekebalan tubuh yang menurun (Santos et al, 2010;. Bowles et al, 2012). Doksorubisin dapat menekan produksi IL-2 dan INF-gamma, sitotoksisitas sel NK, limfositproliferasi dan rasio CD4+/CD8 + di Tumor pada tikus (Zhang et al., 2005). Oleh karena itu, diperlukan agen kokemoterapi yang dapat menekan efek imunosupresi tersebut.

Penggunaan kemoterapi seringkali dikombinasikan dengan suatu agen imunostimulan untuk meningkatkan dan melindungi fungsi kekebalan pasien selama pemberian kemoterapi. Pemberian agen kemoterapi dan agen ko-kemoterapi diharapkan dapat menghasilkan efek terapi yang lebih baik. Salah satunya dengan menggunakan agen imunomodulator yang berasal dari bahan alami seperti tumbuhan.

Tumbuhan yang diduga dapat berfungsi sebagai imunomodulator adalah daun awar-awar terbukti mampu meningkatkan aktivitas sitotoksik agen kemoterapi doksorubisin pada sel kanker payudara MCF-7. Mekanisme molekuler efek sitotoksik ekstrak etanolik daun awar-awar dilakukan dengan pengamatan apoptosis dengan metode double staining dan ekspresi protein Bcl-2 dengan metode imunositokimia. Pengamatan apoptosis dan ekspresi protein Bcl-2 pada aplikasi tunggal ekstrak daun awar-awar menunjukkan kemampuan ekstrak menginduksi apoptosis dan menurunkan ekspresi protein Bcl-2 (Endro et al., 2012)

Sedangkan tanaman lain seperti daun kelor (Moringa oleifera Lam) memiliki kandungan saponin dan flavonoid lebih tinggi. Flavonoid pada daun kelor memiliki peran sebagai antioksidan dan mampu menghentikan reaksi berantai radikal bebas (Bamishaiye et al., 2011; Lakshminarayana et al., 2011). Hasil penelitian lain menunjukkan pemberian ekstrak daun kelor selain meningkatkan jumlah sel T CD4+ juga terbukti dapat meningkatkan jumlah relatif sel T CD8+ (Fathir et al, 2014) serta daun kelor memiliki peran sebagai imunostimulan karena dapat meningkatkan aktivitas makrofag (Biswas et al., 2012). 


\section{JALANNYA PENELITIAN}

Bahan yang digunakan adalah simplisia daun kelor dan daun awar-awar yang diperoleh dari Merapi Farma, $\mathrm{NaCl}$ 0,9\%, doxorubicin , lysing solution (BP FACS), , etanol 96\%, aquadest, Biotinylated rat anti-mouse monoclonal antibodies , 3,3'-diamino-benzidine (DAB, Novo Castra), reagen yang digunakan rat antigen $\mathrm{CD}^{+}$fluorescein isothiocyanate (FITC) (Invitrogen) and phycoerythrin (PE) anti-rat CD8+ (eBioscience). Hewan uji yang digunakan adalah tikus putih galur Sprague Dawley. Alat yang digunakan meliputi seperangkat alat gelas, evaporator, LAB, corong Buchner, vortex, flowcytometer, spuit oral, tabung Eppendorf $5 \mathrm{ml}$, sentrifuge $2500 \mathrm{rpm}$.

\section{Pembuatan Ekstrak}

Daun awar-awar dan daun kelor diekstraksi menggunakan metode maserasi. Dimana $1000 \mathrm{~g}$ daun awar-awar kering dan $1000 \mathrm{~g}$ daun kelor kering diserbuk, setelah itu direndam dalam etanol 96\% $5 \mathrm{~L}$ selama 5 hari. Kemudian disaring dan filtratnya di evaporator sampai terbentuk ekstrak kental.

\section{Perlakuan Terhadap Hewan Uji}

Sebanyak sebanyak 18 tikus dibagi menjadi 7 kelompok, masing- masing kelompok terdiri dari 3 ekor. Selama 7 hari semua kelompok diberi perlakuan sebagai berikut :

Kelompok 1 : kelompok kontrol normal diberi $\mathrm{NaCl} 10 \mathrm{ml} / \mathrm{kgBB}$ secara oral 7 hari berturut-turut.

Kelompok 2 : Kelompok kontrol diberi $\mathrm{NaCl} 10 \mathrm{ml} / \mathrm{kgBB}$ secara oral 7 hari berturut-turut, dilanjutkan dengan doksorubisin 4,67 mg/kgBB pada hari ke 1 dan ke 4 secara intramuskuler.

Kelompok 3 : Kelompok perlakuan diberi ekstrak etanol daun awar-awar $750 \mathrm{mg} / \mathrm{kgBB}$ secara secara oral 7 hari berturut-turut, dilanjutkan dengan doksorubisin $4,67 \mathrm{mg} / \mathrm{kgBB}$ pada hari $\mathrm{ke} 1$ dan $\mathrm{ke} 4$ secara intramuskuler.

Kelompok 4: Kelompok perlakuan diberi ekstrak etanol daun kelor $500 \mathrm{mg} / \mathrm{kgBB}$ secara secara oral 7 hari berturut-turut, dilanjutkan dengan doksorubisin $4,67 \mathrm{mg} / \mathrm{kgBB}$ pada hari ke 1 dan $\mathrm{ke} 4$ secara intramuskuler.

Kelompok 5 : Kelompok perlakuan diberi Kombinasi ekstrak etanol daun awar-awar dan daun kelor 750 $\mathrm{mg} / \mathrm{kgBB}: 500 \mathrm{mg} / \mathrm{kgBB}$ secara secara oral 7 hari berturut-turut, dilanjutkan dengan doksorubisin 4,67 $\mathrm{mg} / \mathrm{kgBB}$ pada hari ke 1 dan ke 4 secara intramuskuler.

Kelompok 6 : Kelompok perlakuan diberi Kombinasi ekstrak etanol daun awar-awar dan daun kelor 750 $\mathrm{mg} / \mathrm{kgBB}: 1000 \mathrm{mg} / \mathrm{kgBB}$ secara secara oral 7 hari berturut-turut, dilanjutkan dengan doksorubisin 4,67 $\mathrm{mg} / \mathrm{kgBB}$ pada hari ke 1 dan ke 4 secara intramuskuler.

\section{Pengambilan Sampel Darah}

Darah diambil dari sinus orbital pada hari ke 0 dan ke 7 untuk pemeriksaan limfosit CD3+ dan CD8+. Dimana sebelum pengambilan darah, tikus dibius menggunakan sodium pentobarbital ( $75 \mathrm{mg} / \mathrm{kg})$.

\section{Pemeriksaan Limfosit CD3+ dan Limfosit CD8+}

Preparasi sampel darah dilakukan dengan cara mencampur $50 \mu 1$ sampel darah, $10 \mu \mathrm{L}$ reagen Invitrogen dan EBioscience setelah itu divortex. Selanjutnya, larutan disimpan dalam ruang gelap selama 15 menit. Tambahkan dengan 45oul BP FACS untuk pengenceran dan vortex, kemudian dibiarkan di ruangan gelap selama 15 menit. Sel dianalisis dengan flowcytometer yang dilengkapi dengan laser argon (eksitasi $488 \mathrm{~nm}$ ) dan pengaturan filter yang sesuai untuk pengamatan FITC fluoresensi. Data berupa persentase dari setiap jenis fluorescent sel yang mewakili jumlah relatif dari $\mathrm{CD}^{+}$dan $\mathrm{CD} 8{ }^{+} \mathrm{T}$ cell limfosit.

Dari data CD3+ limfosit dan CD8 + limfosit akan dianalisis secara statistik menggunakan analisi anova dan LSD untuk membandingkan keadaan antara lebih dari 2 kelompok dengan taraf kepercayaan 95\% untuk melihat perbedaannya.

\section{HASIL DAN PEMBAHASAN}

Hasil penelitian menunjukkan bahwa jumlah relatif $\mathrm{CD}^{+}$dan $\mathrm{CD}^{+}$limfosit kelompok positif (doksorubisin) menunjukkan adanya penurunan secara berturut-turut sebesar 68,07\% dan 48,52\% dibawah nilai kelompok normal CD3+ penurunan sebesar 1,06\%, CD8+ peningkatan sebesar 1,86\%. Secara statistik penurunan jumlah relatif $\mathrm{CD} 3+$ dan $\mathrm{CD} 8+$ limfosit kelompok ini berbeda bermakna dengan kelompok normal $(\mathrm{P}<0,05)$. Hal ini cukup menunjukkan bahwa doxorubin dapat menurunkan sistem imun tubuh dengan menekan jumlah relatif $\mathrm{CD} 3+$ dan $\mathrm{CD} 8^{+}$limfosit didalam tubuh. 
Berdasarkan Gambar 3 dapat dilihat bahwa pemberian kombinasi ekstrak etanol daun awarawar dan daun kelor perbandingan 1:1 dan 1:2 menunjukkan peningkatkan jumlah relatif $\mathrm{CD} 3+$ dan CD8+ limfosit relatif lebih kecil yang secara statistik tidak berbeda bermakna ( $>00,05)$. Jika dibandingkan dengan kelompok kontrol positif.

Kelompok perlakuan ekstrak etanol daun kelor dosis $500 \mathrm{mg} / \mathrm{kgBB}$ mengalami penurunan jumlah relatif $\mathrm{CD}^{+}$dan $\mathrm{CD}^{+}$limfosit secara berturut-turut sebesar $32,08 \%$ dan 30,04\%. Jika dibandingkan dengan kelompok kontrol positif, kelompok ini mengalami penurunan yang lebih kecil dan berbeda bermakna $(p<0,05)$ secara signifikan. Hal ini menunjukkan bahwa kelompok perlakuan ekstrak etanol daun kelor memiliki kemampuan untuk meningkatkan system imun. Peningkatan jumlah $\mathrm{CD}^{+}$dan $\mathrm{CD} 8^{+}$ limfosit dipengaruhi oleh adanya zat aktif di dalam ekstrak etanol daun kelor berupa saponin dan flavonoid yang dapat merangsang peningkatan $\mathrm{IL}-2$ pada sel $\mathrm{T}$ CD4 ${ }^{+}$. Peningkatan IL-2 memungkinkan juga terjadinya peningkatan jumlah $\mathrm{CD}^{+}$dan $\mathrm{CD}^{+}$limfosit (Mc Nally et al., 2011).
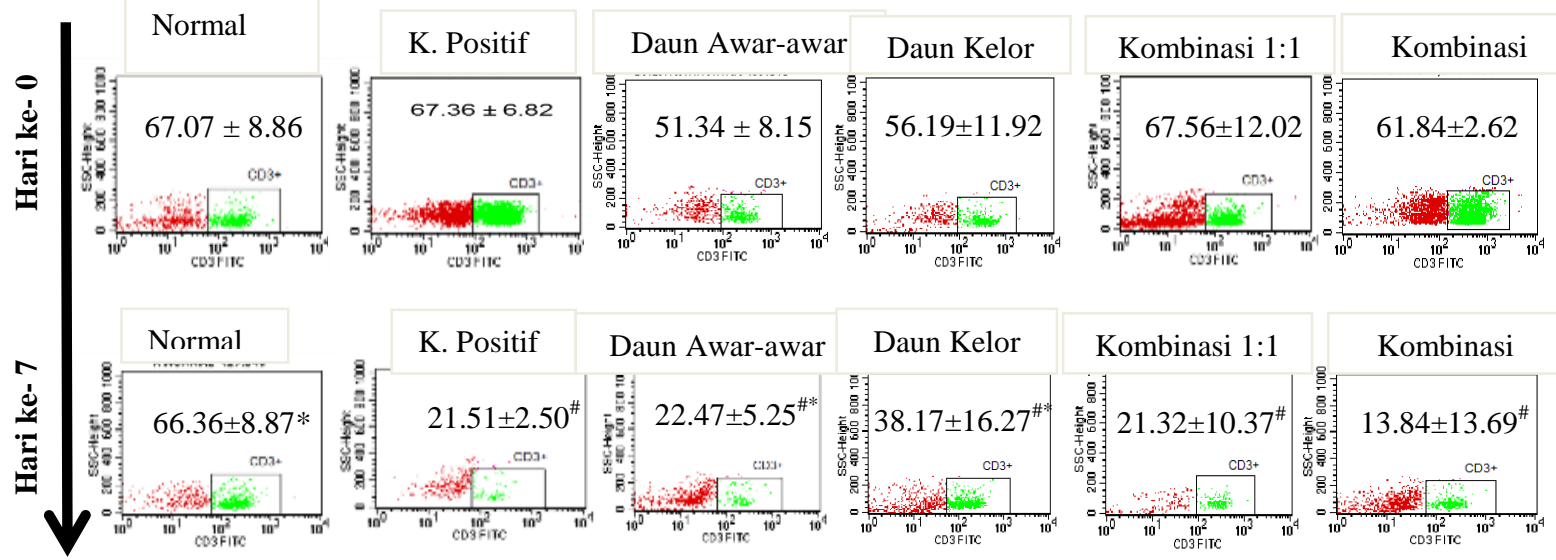

\section{Gambar 1. Rerata jumlah relatif $\mathrm{CD3}^{+}$limfosit sebelum dan sesudah pemberian doksorubisin dengan analisis flowcymetri.}

Keterangan :

\# : berbeda signifikan dengan kelompok normal $\mathrm{p}<0,05)$

* : berbeda signifikan dengan kelompok positif $(\mathrm{p}<0,05)$

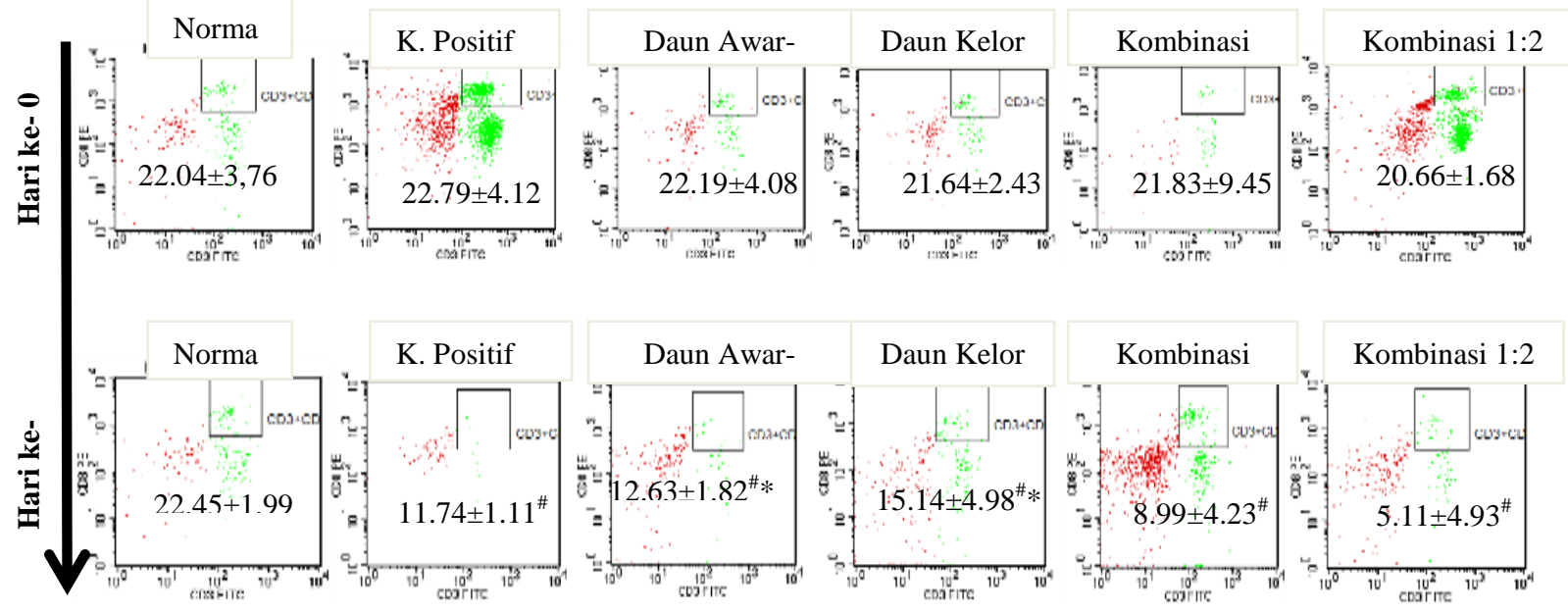

Gambar 2. Rerata jumlah relatif $\mathrm{CD8}^{+}$limfosit sebelum dan sesudah pemberian doksorubisin dengan analisis flowcymetri.

Keterangan :

\# : berbeda signifikan dengan kelompok normal $\mathrm{p}<0,05)$

* : berbeda signifikan dengan kelompok positif $(p<0,05)$ 


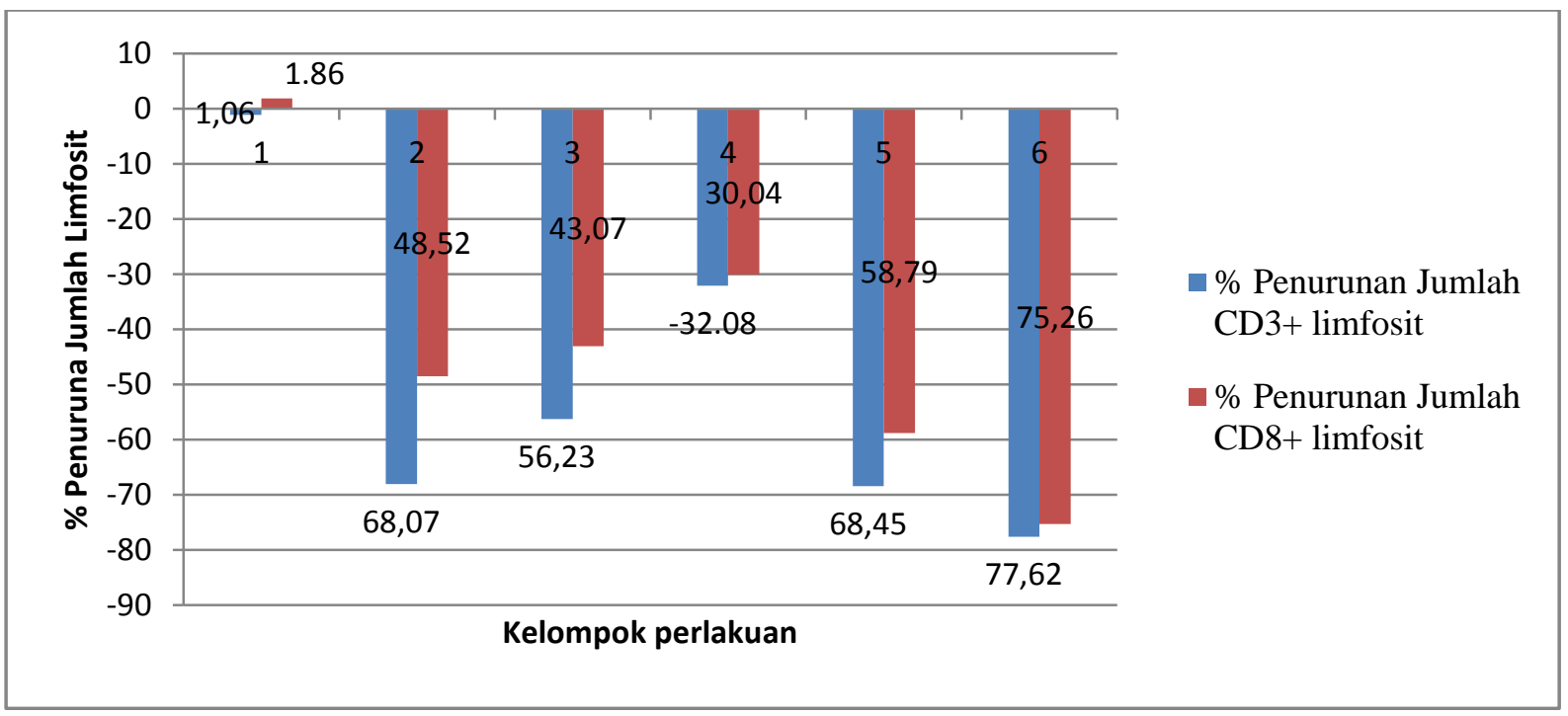

\section{Gambar 3. Persentase penurunan jumlah relaif $\mathrm{CD3}^{+}$dan $\mathrm{CD8}^{+}$limfosit sesudah pemberian doksorubisin.}

Keterangan:

$1:$ kelompok normal

2 : kelompok positif

3 : kelompok ekstrak etanol daun awar-awar

$4:$ kelompok ekstrak etanol dan daun kelor

5 : kelompok kombinasi ekstrak etanol daun awar-awar dan ekstrak etanol dan daun kelor perbandingan 1:1

6 : kelompok kombinasi ekstrak etanol daun awar-awar dan ekstrak etanol dan daun kelor perbandingan 1:2

Kelompok perlakuan ekstrak etanol daun awar-awar dosis $750 \mathrm{~g} / \mathrm{kgBB}$ mengalami penurunan

jumlah relatif $\mathrm{CD}^{+}$dan $\mathrm{CD}^{+}$limfosit secara berturut-turut sebesar 56,23\% dan 43,07\%. Jika dibandingkan dengan kelompok kontrol negatif kelompok ini mengalami penurunan yang berbeda bermakna $(\mathrm{p}<0,05)$ secara signifikan. Hal ini menunjukkan bahwa kelompok perlakuan ekstrak etanol daun awar-awar dapat meningkatkan sistem imun. Hal ini mungkin disebabkan karena dosis yang terlalu rendah ataupun terlalu tinggi. Sehingga diperlukan adanya evaluasi dosis yang lebih lanjut.

\section{KESIMPULAN}

Kombinasi ekstrak etanol daun awar-awar dan daun kelor perbandingan 1:1 dan 1:2 dalam meningkatkan sistem imun relatif kecil yang secara statistik tidak berbeda bermakna $(p>0,05)$. Namun pemberian ekstrak etanol daun awar-awar dan ekstrak etanol daun kelor secara terpisah memiliki kemampuan meningkatkan sistem imun yang relatif besar yang secara statistik berbeda bermakna $(\mathrm{p}<0,05)$.

\section{DAFTAR PUSTAKA}

Bamishaiye, E.I.F.F., Olayemi, E.F., Awagu, Bamshaiye, O.M., 2011, Proximate and phytochemical composition of Moringa oleifera leaves at three stages of maturation. Advance Journal of Food Science and Technology $3: 233-237$

Biswas, S.K, Chowdhury, A., Joysre, D., Ajoy, R., Zahid, H., 2012, Pharmacological potentials of Moringa oliefera Lam, A Review. International Journal Pharmaceutical Sciences and Research $3: 305-310$

Bowles, E.J, Wellman, R., Feigelson, H.S., 2012, Risk of heart failure in breast cancer patients after anthracycline and trastuzumab treatment: a retrospective cohort study, J Natl Cancer Inst, 104, 1293-305

Dalimartha, D.S., 2007, Ramuan Tradisional Pengobatan Kanker, Penebar swadaya, Jakarta

Endro, A.E., Hermawan, A., Nastiti, K., 2012, Immunomodulatory Effects of Hexane Insoluble Fraction of Ficus septica Burm. F. in Doxorubicin-treated Rats, Asian Pacific Journal of Cancer Prevention Vol 13 
Fathir, A., Muhaimin, R., Widodo, 2014, Aktivitas Ekstrak Daun Kelor Terhadap Sel-T Helper dan SelT Sitotoksik pada Mencit yang Diinfeksi Salmonella thypi, Jurnal Veteriner, Vol.15, 114-122

Hanahan, D., and Weinberg, P.A., 2000, The Hallmarks of Cancer Cell, Cell, 100(1), 57-70

Lakshminarayana, M., Shivkumar, H., Rimaben, P., Bhargava, V.K., 2011, Antidiarrhoeal activity of leaf extract of Moringa oleifera in experimentally induced diarrhoea in rats, International Journal of Phytomedicine $3: 68-74$

Mc Nally A, Geffery R H, Tim S, Ranjeny T, Raymond J S. 2011. CD4+CD25+ regulatory T cells control CD8+ T cell effector differentation by modulating IL-2 homeostasis. PNAS 8 : 75297534.

Santos, R.V.T., Caperuto, E.C., Mello, M.T., 2010, Effect of doxorubicin on cytokine production by lymphocytes and the Th1/Th2 balance. Biomedicine \& Pharmacotherapy, 64, 579-81

Tan, M.L., Choong, P.F., Dass, C.R., 2009, Review: doxorubicin delivery systems based on chitosan for cancer therapy, J Pharm Pharmacol, 61, 131-42

WHO, 2011, Cancer, World Health Organization, Switzerland, diakses tanggal agustus 2014, http://www.who.int/mediacentre/factsheet s/fs297/en/

Zhang, X.Y., Li, W.G., Wu, Y.J., 2005, Proanthocyanidin from grape seeds potentiates anti-tumor activity of doxorubicin via immunomodulatory mechanism. Int Immunopharmacol, 5, 1247-57 